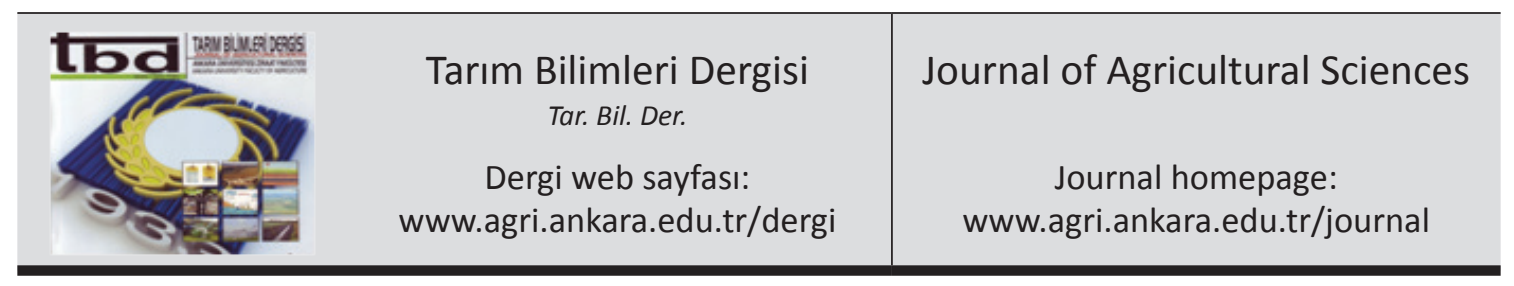

\title{
Determination of Genotypic Variation among Sorghum Cultivars for Seed Vigor, Salt and Drought Stresses
}

\author{
Süleyman AVCI ${ }^{a}$, Onur İLERİ ${ }^{a}$, Mehmet Demir KAYA ${ }^{a}$ \\ ${ }^{a}$ Eskisehir Osmangazi University, Faculty of Agriculture, Department of Field Crops, Eskişehir, TURKEY
}

\section{ARTICLE INFO}

Research Article

DOI: 10.15832 /ankutbd. 447645

Corresponding Author: Mehmet Demir KAYA, E-mail: demirkaya76@hotmail.com, Tel: +90 (222) 3242990 Received:

26 January 2015, Received in Revised Form: 31 December 2015, Accepted: 22 January 2016

\begin{abstract}
This study was conducted to determine genotypic variation among sorghum cultivars grown under similar ecological conditions for seed vigor, salt $(\mathrm{NaCl})$ and drought stresses. A seedling survival test was also performed in a pod experiment to investigate genotypic differences in terms of sorghum drought tolerance. In seven sorghum cultivars, seed vigor was determined using electrical conductivity and accelerated ageing tests. Also, germination rate and seedling growth of these cultivars were evaluated under salt and drought stress induced by PEG 6000 at water potentials of 0.0 (distilled water) $,-1.8,-3.6,-7.2$ and -10.8 bar. The results showed that there was a significant difference in seed vigor of sorghum cultivars grown at same ecological conditions. Akdarı produced more vigorous seeds than the other cultivars. The significant relationship between accelerated ageing and laboratory emergence $(\mathrm{r}=0.967 * *)$, and between electrical conductivity and germination percentage $\left(\mathrm{r}=-0.873^{* *}\right)$ were determined. The suitable tests for germination and emergence potential in sorghum were electrical conductivity and accelerated ageing, respectively. Increasing $\mathrm{NaCl}$ and PEG levels inhibited germination and seedling growth. Germination, root length and shoot length were higher, whereas mean germination time was lower, in $\mathrm{NaCl}$ solution compared to in PEG solution at the same water potential. In salt, drought and seedling survival tests, Aldarı showed the better performance than the others. It could be concluded that seed vigor is not a reliable indicator of germination performance under salt and drought stress conditions and that genetic differences may play an important role in stress tolerance.
\end{abstract}

Keywords: Sorghum bicolor L.; Accelerated ageing; Salinity; Drought; Germination; Cultivar

\section{Sorgum Çeşitleri Arasında Tohum Gücü, Tuz ve Kuraklık Stresi Bakımından Genotipik Varyasyonun Belirlenmesi}

\section{ESER BILGISII}

Araştırma Makalesi

Sorumlu Yazar: Mehmet Demir KAYA, E-posta: demirkaya76@hotmail.com, Tel: +90 (222) 3242990

Geliş Tarihi: 26 Ocak 2015, Düzeltmelerin Gelişi: 31 Aralık 2015, Kabul: 22 Ocak 2016

\section{ÖZET}

$\mathrm{Bu}$ çalışma aynı ekolojik koşullarda yetiștirilen sorgum çeşitleri arasında tohum gücü, tuz ( $\mathrm{NaCl}$ ) ve kuraklık stresi bakımından genetik farklılıkların belirlenmesi amacıyla yürütülmüştür. Ayrıca sorgum çeşitleri arasında kuraklık stresine 
toleransın belirlenmesi amacıyla saksı denemesi olarak fide canlılık testi yapılmıştır. İncelenen 7 sorgum çeşidinde tohum gücü, elektriksel iletkenlik ve hızlı yaşlandırma testleriyle belirlenmiştir. PEG 6000 ve NaCl kullanarak su tutma gücü 0.0 (saf su), -1.8, -3.6, -7.2 ve -10.8 bar olarak ayarlanan solüsyonlarda çeşitlerin çimlenme ve fide gelişimi incelenmiştir. Araştırma sonuçlarına göre, aynı ekolojik koşullarda yetiştirilen sorgum çeşitlerinin tohum güçleri arasında önemli farklılıkların olduğu belirlenmiştir. Akdarı çeşidi diğer çeşitlere göre daha güçlü tohum üretmiştir. Tohum güç testlerinden hızlı yaşlandırma ile laboratuvar çıkışı arasında $\left(\mathrm{r}=0.967^{* *}\right)$ ve elektriksel iletkenlik ile çimlenme arasında $\left(\mathrm{r}=-0.873^{* *}\right)$ önemli ilişkilerin olduğu belirlenmiştir. Sorgum çeşitlerinin çimlenme potansiyelini belirlemede elektriksel iletkenlik testi, çıkış performansının belirlenmesinde ise hızlı yaşlandırma testi uygun bulunmuştur. Artan $\mathrm{NaCl}$ ve PEG konsantrasyonları çimlenme ve fide gelişimini engellemiştir. $\mathrm{NaCl}$ ile karşılaştırıldığında, PEG solüsyonlarında çimlenme, kök ve sürgün uzunluğu daha yüksek, ortalama çimlenme süresi daha kısa bulunmuştur. Tuz, kuraklık ve fide canlılık testlerinde, Aldarı çeşidinin diğer çeşitlerden daha yüksek performans göstermiştir. Sonuç olarak, tohum güç testlerinin tuz ve kuraklık stresinde çimlenme performansı için güvenilebilir olmadığı ve genetik farklılıkların stres toleransında önemli rol oynadı̆̆ söylenebilir.

Anahtar Kelimeler: Sorghum bicolor L.; Hızlı yaşlandırma; Tuzluluk; Kuraklık; Çimlenme; Çeşit

(C) Ankara Üniversitesi Ziraat Fakültesi

\section{Introduction}

Sorghum (Sorghum bicolor (L.) Moench), a crop native to Sub-Saharan Africa, is widely used for multiple purposes, such as feed, food, fiber and fuel (Tari et al 2013). Sorghum is adapted to semiarid tropical regions and produces a reasonable yield under high temperatures, high radiation, high evaporative demand, unreliable and irregular rainfall and soil properties of low fertility and low water holding capacity, all of which cause detrimental effects on seed germination and seedling growth as well as plant survival (Doggett 1988; Mutavaa et al 2011).

Osmotic stress created by salinity and drought represents one of the major yield constraints in many parts of the world (Araus et al 2002; Munns 2002; Kandil et al 2012). This type of stress adversely affects crop plants at all life cycle stages, with germination and seedling establishment being more sensitive than subsequent growth stages (Khan \& Gulzar 2003; El Naim et al 2012). Drought and salt stress tolerance in sorghum has been investigated in previous studies by Smith et al (1989), Igartua et al (1994), Maiti et al (1994), Kaur Gill et al (2002) and Ambika et al (2011); however, limited information about the relationship between germination performance under these stresses and seed vigor of sorghum.
A germination test determines the viability of seeds but it fails to estimate field performance, as the seedbed conditions at planting are less than optimum. The seedbed conditions can impose moderate to severe stress on the seed, thereby delaying or preventing germination (TeKrony \& Egli 1991). These stress conditions can lead to decreased emergence rates, namely, lower values reported by the germination test. Seed vigor tests, including emergence, osmotic stress generated by $\mathrm{NaCl}$ and $\mathrm{PEG}$, temperature, conductivity and accelerated ageing provide more sensitive measures of physiological seed quality, which more accurately reflect a seed lot's potential performance (McDonald 1993; Milosevic et al 2010).

This study aimed to investigate differences in seed vigor of sorghum cultivars grown under the same ecological conditions and to determine whether seed vigor influences germination under drought and salt stress conditions.

\section{Material and Methods}

This study was conducted at the seed science laboratory of the Field Crops Department, Agricultural Faculty, Eskisehir Osmangazi University, Turkey. Seeds of sorghum cultivars Aldarı, Akdarı, Beydarı, Gözde-80, Greengo, Leoti and Rox were harvested from the experimental 
fields at Eskisehir Osmangazi University in 2011. All of the seeds were stored at $4{ }^{\circ} \mathrm{C}$ prior to the start of the experiment.

Germination test: Four replicates of 50 seeds from each cultivar were germinated on three rolled filter papers with $10 \mathrm{~mL}$ of distilled water. Each rolled paper was placed in a sealed plastic bag to prevent moisture loss. Seeds were allowed to germinate at $25 \pm 1{ }^{\circ} \mathrm{C}$ in the dark for 10 days. Seeds were considered to have germinated when the emerging radicle was at least $2 \mathrm{~mm}$ long. Germination percentage (GP) was recorded every $24 \mathrm{~h}$ for 10 days. Mean germination time (MGT) was calculated to assess the speed of germination (ISTA 2003).

Salt and drought stres: Germination and early seedling growth of the cultivars were studied under osmotic potentials of $-1.8,-3.6,-7.2$ and -10.8 bar, produced by either $\mathrm{NaCl}$ or polyethylene glycol (PEG 6000) (Michel \& Kaufmann 1973). NaCl concentrations had the electrical conductivity (EC) values of 5, 10, 20 and $30 \mathrm{dS} \mathrm{m}^{-1}$. The germination test results were used as a control.

For the seed vigor tests accelerated ageing (AA) test, electrical conductivity (EC) test, emergence test and seedling survival test were conducted as detailed below.

Accelerated ageing (AA) test: Two hundred seeds were sampled from each cultivar. Using an ageing temperature and time combination of 45 ${ }^{\circ} \mathrm{C}$ for $144 \mathrm{~h}$, the AA test was performed in plastic boxes $(11 \times 11 \times 4 \mathrm{~cm})$ to which $40 \mathrm{~mL}$ of distilled water was added (Hampton \& TeKrony 1995). Seeds were uniformly distributed on wire mesh trays $(10 \times 10 \times 3 \mathrm{~cm})$, which were placed inside the boxes. After ageing, 50 seeds per replicate were allowed to germinate on filter paper at $25 \pm 1{ }^{\circ} \mathrm{C}$ in a dark growth chamber for 10 days.

Electrical conductivity (EC) test: The electrolyte leakage was measured for four replicates of 50 weighed seeds from each ageing combination. Seeds were immersed in $50 \mathrm{~mL}$ deionized water at $25 \pm 1$ ${ }^{\circ} \mathrm{C}$ for $24 \mathrm{~h}$ (ISTA 2003). The electrical conductivity of soaked water was measured using a conductivity meter (Model WTW Cond 314i, Germany). Results were expressed in $\mu \mathrm{S} \mathrm{cm}^{-1} \mathrm{~g}^{-1}$ to take into account any variability in seed weight among the seed lots.

Emergence test: Four replicates of 50 seeds from each cultivar were sown at a $2 \mathrm{~cm}$ depth in sandfilled seedling trays $(30 \times 20 \times 7 \mathrm{~cm})$ to determine laboratory emergence percentage (LEP) under salinity stress. Seedlings were grown in an incubator set at $25 \pm 1{ }^{\circ} \mathrm{C}$ for 10 days. The emerged seedlings (identified by the appearance of hypocotyls at the surface) were counted at ten days after sowing.

Seedling survival test: Seven sorghum cultivars were tested for water stress tolerance at the seedling growth stages described by Hameed et al (2010). Ten seeds were sown at a depth of $1.5 \mathrm{~cm}$ in a plastic pot $(24 \times 19 \mathrm{~cm})$ filled with an equal quantity of field soil. All of the pots were irrigated to the soil water holding capacity every other day during the experiment. Once each plant reached the stage where it had 5 leaves, irrigation was no longer provided. Data were recorded for percent wilting due to drought for 15 days.

The experiment was arranged in a completely randomized design (CRD) with four replicates and 50 seeds per replicate. Germination percentage data were subjected to arcsine transformation before analysis of variance was performed using the MSTAT-C program (Michigan State University). The differences among the means were compared using the LSD values $(\mathrm{P}<0.05)$.

\section{Results and Discussion}

The standard germination test showed significant differences among the sorghum cultivars. The lowest germination rate was obtained in Gözde $80(89.5 \%)$, while higher values were obtained from Akdarı and Leoti with $100 \%$ than the others (Figure 1). When the germination decreased EC values increased considerably. The highest EC value was recorded in Gözde 80. Accelerated ageing resulted in decreased germination in all cultivars. Significant decreases in germination percentage of Gözde 80 and Greengo were detected. The highest germination percentage in the accelerated ageing 
test was detected in Akdarı (96.5\%). The laboratory emergence test demonstrated that the Gözde 80 had the lowest emergence percentage $(79.0 \%)$, while Akdarı was superior to all of the other sorghum cultivars. Correlation coefficient between laboratory emergence and accelerated ageing was positive and significant $\left(\mathrm{r}=0.967^{* *}\right)$. The cultivars with lower germination percentages had lower emergence percentages but higher electrical conductivity values. Significant and negative correlation coefficient $\left(\mathrm{r}=-0.873^{* *}\right)$ were determined between germination percentage and electrical conductivity. In other words, germination and emergence of sorghum cultivars were negatively correlated with electrical conductivity. The conductivity test has been suggested as a method to evaluate seed vigor of pea and soybean (Hampton \& TeKrony 1995). Furthermore, this test has been routinely used for other crops in seed laboratories due to its simplicity and potential for rapid implementation. Our findings indicate that electrical conductivity might be a satisfying indicator of seed vigor of sorghum cultivars, as similar results were obtained from the accelerated ageing test. Soares et al (2010) reported that the electrical conductivity test should only be used if the seed lots with low vigor have been identified. The detrimental effect of accelerated ageing was more prominent in Gözde 80 and Greengo. These results agree with those reported by Santipracha et al (1997) in corn and Cisse \& Ejeta (2003) in sorghum. Furthermore, they confirm that genetic differences may play an important role in determining seed vigor. Based on the results of the accelerated ageing test along with laboratory emergence, the sorghum cultivars were arranged as Akdar $>$ Leoti $>$ Beydar $1>$ Rox $>$ Aldar $>$ G reengo $>$ Gözde 80 in terms of decreasing seed vigor. The electrical conductivity test results suggested a different sequence as Akdar $>$ Aldar $>$ Leoti $>$ Greeng o $>$ Rox $>$ Beydarı $>$ Gözde 80 (Figure 1).

A significant $(\mathrm{P}<0.05)$ two-way interaction (genotype and $\mathrm{NaCl}$ ) was found for all investigated characters under salt stress. The germination percentage was significantly reduced at $\mathrm{NaCl}$ levels of $20 \mathrm{dS} \mathrm{m}^{-1}$. The minimum germination were detected

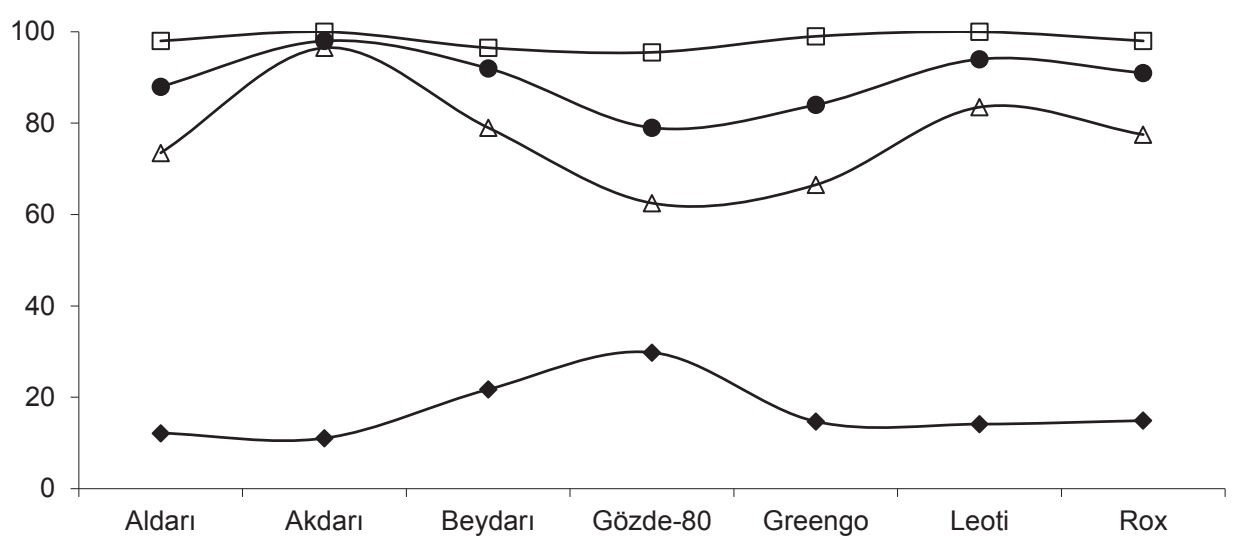

Figure 1- Germination percentage $(\square)$, laboratory emergence $(\bullet)$, germination after accelerated ageing $(\Delta)$ at $45^{\circ} \mathrm{C}$ for $144 \mathrm{~h}$ and electrical conductivity ( $\left.\downarrow\right)$ for $24 \mathrm{~h}$ results for the seven sorghum cultivars used in this study, significant correlation coefficients between germination and electrical conductivity $(r=-0.873 * *)$, laboratory emergence and accelerated ageing $(\mathrm{r}=0.967 * *)$ were determined

Şekil 1-Araştırmada kullanılan sorgum çeşitlerinin çimlenme yüzdesi (口), laboratuvar çıkış (•), $45{ }^{\circ} \mathrm{C}$ 'de 144 saat hızl yaşlandırma sonrası çimlenme $(\Delta)$ ve 24 saat sonra elektriksel iletkenlik $(\downarrow)$, çimlenme ve elektriksel iletkenlik arasında $\left(r=-0.873^{* *}\right)$, laboratuvar çıkışı ve hızl yaşlandırma arasında $(r=0.967 * *)$ önemli korelasyon katsayıları belirlenmiştir 
in Gözde $80(7.5 \%)$, while the highest germination percentage $(74.0 \%$ ) was detected in Aldar1 at the $\mathrm{NaCl}$ concentration of $30 \mathrm{dS} \mathrm{m}^{-1}$ (Table 1). The MGT was delayed by increasing the degree of salinity stress, on $\mathrm{NaCl}$ level of $20 \mathrm{dS} \mathrm{m}^{-1}$ retarded MGT considerably compared to lower levels of $\mathrm{NaCl}$. Due to insufficient germination, the MGT was not calculated at $30 \mathrm{dS}$ $\mathrm{m}^{-1}$, except in Aldarı. The most rapid germination at $20 \mathrm{dS} \mathrm{m}^{-1}$ occurred in Aldarı after $2.67 \mathrm{~d} . \mathrm{NaCl}$ adversely affected the germination percentage and mean time to germination in sorghum cultivars, and inhibitory effects of $\mathrm{NaCl}$ on germination could be detected at $30 \mathrm{dS} \mathrm{m}^{-1}$. Among the sorghum cultivars, Akdar1 had the highest emergence percentage $(98.0 \%)$ in the control treatment, while Beydar1 had the highest emergence proportion $(85.0 \%)$ at the $\mathrm{NaCl}$ level of $10 \mathrm{dS} \mathrm{m}^{-1}$. At the highest salt concentration, the maximum emergence percentage was recorded in Leoti (13.0\%) (Table 1). The final germination percentage was markedly reduced at the $\mathrm{NaCl}$ level of $20 \mathrm{dS} \mathrm{m} \mathrm{m}^{-1}$ however mean germination time increased as $\mathrm{NaCl}$ levels increased. However, Tabatabaei \& Anagholi (2012) found that $\mathrm{NaCl}$ levels between 0 and $15 \mathrm{dS} \mathrm{m}^{-1}$ did not adversely affect the germination percentage. Similar results were reported by Francois et al (1984), Maiti et al (1994), Faheed et al (2005) and Kandil et al (2012) whom determined that germination and seedling growth were reduced in saline soils with responses varying depending on the cultivar while $\mathrm{NaCl}$ diminished the germination of seeds by creating an external osmotic potential, thereby preventing water uptake. Increased drought stress resulted in decreased germination and seedling growth, especially at salinity levels higher than -7.2 bar, which is in line with earlier observations made by Kaur Gill et al (2002). Saint-Clair (1976) determined a close relationship between germination under drought stress induced by PEG and field drought tolerance in 11 sorghum cultivars.

Generally, increasing salinity levels decreased root length except Rox, and Greengo and Leoti exhibited the longer roots than the others. Root growth was not detected in Aldarı, Akdarı and Rox at $20 \mathrm{dS} \mathrm{m}^{-1} \mathrm{NaCl}$. The shoot lengths of nearly all of the sorghum cultivars did not change significantly at salinity levels up to $20 \mathrm{dS} \mathrm{m} \mathrm{m}^{-1}$. None of the genotypes observed in this study were able to grow shoots at salinity levels of $30 \mathrm{dS} \mathrm{m} \mathrm{m}^{-1}$. At $20 \mathrm{dS} \mathrm{m}^{-1}$, Leoti was superior to the other cultivars, exhibiting a shoot length of $6.87 \mathrm{~cm}$. Greater reductions in seedling fresh weight due to $\mathrm{NaCl}$ were significantly prominent at $20 \mathrm{dS} \mathrm{m}^{-1}$, and no shoot growth was observed at $30 \mathrm{dS} \mathrm{m}^{-1}$. $\mathrm{NaCl}$ enhanced shoot growth at salinity concentrations up to $10 \mathrm{dS} \mathrm{m}^{-1}$ but inhibited shoot growth dramatically at $20 \mathrm{dS} \mathrm{m}^{-1}$. Seedling dry weight showed a trend similar to that of fresh weight, and Leoti, Greengo and Gözde 80 produced seedling dry weights at $20 \mathrm{dS} \mathrm{m}^{-1}$.

Drought stress induced by PEG adversely affected germination and seedling growth of sorghum cultivars. Higher germination rates were obtained in Aldarı (28.5\%) and in Beydarı (13.0\%) at a PEG level of -10.8 bar (Table 2). Increased drought stress delayed the mean germination time. The shortest MGT (2.49 d) at -7.2 bar was observed in Aldarı. Seedling growth of the sorghum cultivars was severely influenced by increasing drought stress. No shoot and root development and subsequently no seedling fresh and dry weights were observed at a drought stress level of -7.2 bar in all cultivars. Leoti and Gözde 80 developed shoots and roots at drought stress levels of -1.8 and -3.6 bar. As no shoot growth was recorded under higher levels of drought stress, seedling fresh and dry weights were not evaluated. Each increase in PEG level caused a remarkable decrease in seedling fresh weight for all cultivars. However, the changes in seedling dry weight of Beydarı, Gözde 80, Greengo and Leoti due to drought stress were not significant. Apparent genetic differences were found among the sorghum cultivars subjected to salt and drought stresses with respect to seedling growth. Root and shoot length, in addition to seedling fresh and dry weight, decreased under increasing salt and drought concentrations. In terms of germination and seedling growth, cultivars were arranged in the following order, based on performance under $\mathrm{NaCl}$ stress as Aldarl $>$ Greengo $>$ Rox $>$ Beydarl $>$ Leoti $>$ Akdarl $>$ Gözde 80 . The order of cultivars under drought stress was Aldar $>$ Greeng o $>$ Beydarı $>$ Rox $>$ Leoti $>$ Akdarı $>$ Gözde 80 . 
Table 1- Germination and seedling growth of sorghum cultivars under different $\mathrm{NaCl}$ levels*

Çizelge 1- Farkl $\mathrm{NaCl}$ seviyelerinde sorgum çeşitlerinin çimlenme ve fide gelişimi*

\begin{tabular}{|c|c|c|c|c|c|c|c|c|}
\hline $\begin{array}{l}\text { Sorghum } \\
\text { cultivars }\end{array}$ & $\begin{array}{c}\mathrm{NaCl} \\
\left(d S m^{-1}\right)\end{array}$ & $\begin{array}{c}\text { Germination } \\
(\%)\end{array}$ & $\begin{array}{l}M G T \\
\text { (d) }\end{array}$ & $\begin{array}{c}\text { Emergence } \\
(\%)\end{array}$ & $\begin{array}{l}\text { Root length } \\
\quad(\mathrm{cm})\end{array}$ & $\begin{array}{l}\text { Shoot length } \\
\text { (cm) }\end{array}$ & $\begin{array}{c}\text { Seedling } \\
\text { fresh weight } \\
\left(\mathrm{mg} \mathrm{plant}^{-1}\right)\end{array}$ & $\begin{array}{c}\text { Seedling } \\
\text { dry weight } \\
\left(m^{2} \text { plant }^{-1}\right)\end{array}$ \\
\hline \multirow{5}{*}{ Aldarı } & 0 & $100.0 \pm 0.00$ & $1.96 \pm 0.02$ & $88.0 \pm 5.65$ & $10.52 \pm 0.72$ & $11.17 \pm 0.38$ & $85.87 \pm 5.13$ & $10.40 \pm 0.33$ \\
\hline & 5 & $96.5 \pm 3.41$ & $2.03 \pm 0.05$ & $73.0 \pm 5.03$ & $11.52 \pm 1.16$ & $9.42 \pm 0.68$ & $63.20 \pm 6.25$ & $9.00 \pm 0.55$ \\
\hline & 10 & $92.5 \pm 2.51$ & $2.11 \pm 0.07$ & $49.0 \pm 6.83$ & $10.67 \pm 0.57$ & $7.46 \pm 0.80$ & $50.20 \pm 6.17$ & $8.35 \pm 0.36$ \\
\hline & 20 & $89.5 \pm 2.51$ & $2.67 \pm 0.23$ & $2.0 \pm 2.30$ & - & - & - & - \\
\hline & 30 & $74.0 \pm 4.32$ & $4.16 \pm 0.26$ & $0.0 \pm 0.0$ & - & - & - & - \\
\hline \multirow{5}{*}{ Akdarı } & 0 & $98.0 \pm 2.82$ & $2.59 \pm 0.08$ & $98.0 \pm 2.30$ & $8.57 \pm 1.17$ & $8.41 \pm 0.42$ & $84.77 \pm 8.73$ & $8.60 \pm 0.64$ \\
\hline & 5 & $96.0 \pm 3.65$ & $2.89 \pm 0.11$ & $95.0 \pm 2.00$ & $8.15 \pm 0.98$ & $8.45 \pm 0.34$ & $66.42 \pm 5.26$ & $7.27 \pm 0.49$ \\
\hline & 10 & $90.0 \pm 5.41$ & $3.19 \pm 0.06$ & $84.5 \pm 3.41$ & $7.75 \pm 0.51$ & $7.36 \pm 0.26$ & $52.42 \pm 3.00$ & $6.62 \pm 0.26$ \\
\hline & 20 & $64.0 \pm 8.79$ & $4.71 \pm 0.15$ & $49.0 \pm 6.00$ & - & - & - & - \\
\hline & 30 & $21.5 \pm 6.40$ & - & $7.0 \pm 6.00$ & - & - & - & - \\
\hline \multirow{5}{*}{ Beydar1 } & 0 & $96.5 \pm 3.00$ & $2.18 \pm 0.06$ & $92.0 \pm 0.0$ & $10.83 \pm 1.59$ & $7.22 \pm 0.31$ & $24.02 \pm 0.55$ & $7.97 \pm 0.25$ \\
\hline & 5 & $91.5 \pm 3.41$ & $2.26 \pm 0.05$ & $88.0 \pm 10.83$ & $11.31 \pm 0.96$ & $6.63 \pm 0.54$ & $31.02 \pm 2.03$ & $8.05 \pm 0.36$ \\
\hline & 10 & $86.0 \pm 4.00$ & $2.65 \pm 0.07$ & $85.0 \pm 3.82$ & $9.76 \pm 0.99$ & $7.33 \pm 0.52$ & $27.55 \pm 2.43$ & $7.30 \pm 0.54$ \\
\hline & 20 & $67.0 \pm 6.63$ & $3.37 \pm 0.20$ & $59.0 \pm 6.00$ & $4.22 \pm 2.82$ & $2.86 \pm 1.91$ & $9.82 \pm 6.57$ & $2.95 \pm 1.97$ \\
\hline & 30 & $31.5 \pm 9.00$ & - & $12.0 \pm 3.26$ & - & - & - & - \\
\hline \multirow{5}{*}{ Gözde 80} & 0 & $78.5 \pm 5.25$ & $2.94 \pm 0.11$ & $79.0 \pm 6.83$ & $13.26 \pm 1.09$ & $8.57 \pm 0.49$ & $73.90 \pm 7.71$ & $7.72 \pm 0.43$ \\
\hline & 5 & $73.5 \pm 9.00$ & $2.75 \pm 0.12$ & $64.0 \pm 5.65$ & $12.56 \pm 0.19$ & $9.42 \pm 0.74$ & $71.65 \pm 2.31$ & $6.97 \pm 0.12$ \\
\hline & 10 & $63.5 \pm 7.72$ & $3.15 \pm 0.32$ & $58.0 \pm 6.92$ & $12.36 \pm 0.67$ & $9.32 \pm 0.53$ & $61.15 \pm 4.21$ & $6.27 \pm 0.17$ \\
\hline & 20 & $32.0 \pm 0.0$ & - & $23.0 \pm 6.00$ & $3.37 \pm 3.93$ & $2.67 \pm 3.11$ & $31.60 \pm 4.77$ & $3.60 \pm 0.54$ \\
\hline & 30 & $7.5 \pm 4.72$ & - & $4.0 \pm 3.26$ & - & - & - & - \\
\hline \multirow{5}{*}{ Greengo } & 0 & $99.0 \pm 1.15$ & $2.14 \pm 0.15$ & $84.0 \pm 6.53$ & $12.61 \pm 1.56$ & $9.33 \pm 0.87$ & $58.75 \pm 18.13$ & $6.52 \pm 2.52$ \\
\hline & 5 & $90.5 \pm 5.74$ & $2.70 \pm 0.25$ & $63.0 \pm 9.45$ & $12.15 \pm 1.31$ & $8.35 \pm 0.34$ & $41.67 \pm 4.40$ & $4.35 \pm 0.55$ \\
\hline & 10 & $82.5 \pm 4.43$ & $2.41 \pm 0.12$ & $21.0 \pm 8.24$ & $11.62 \pm 0.83$ & $7.07 \pm 0.68$ & $75.20 \pm 4.66$ & $8.60 \pm 0.70$ \\
\hline & 20 & $72.0 \pm 4.89$ & $3.97 \pm 0.31$ & $0.0 \pm 0.0$ & $7.50 \pm 0.55$ & $3.78 \pm 0.73$ & $32.22 \pm 2.88$ & $4.65 \pm 0.36$ \\
\hline & 30 & $44.5 \pm 10.87$ & - & $0.0 \pm 0.0$ & - & - & - & - \\
\hline \multirow{5}{*}{ Leoti } & 0 & $100.0 \pm 0.00$ & $1.99 \pm 0.03$ & $94.0 \pm 2.30$ & $11.18 \pm 1.55$ & $10.25 \pm 0.86$ & $77.52 \pm 4.13$ & $9.37 \pm 0.09$ \\
\hline & 5 & $100.0 \pm 0.00$ & $2.13 \pm 0.03$ & $94.0 \pm 2.30$ & $9.27 \pm 0.32$ & $12.71 \pm 0.28$ & $68.90 \pm 4.75$ & $8.30 \pm 0.45$ \\
\hline & 10 & $97.0 \pm 1.15$ & $2.26 \pm 0.12$ & $78.0 \pm 5.16$ & $9.65 \pm 0.49$ & $12.16 \pm 0.54$ & $50.77 \pm 5.41$ & $7.75 \pm 0.44$ \\
\hline & 20 & $89.0 \pm 2.00$ & $3.27 \pm 0.07$ & $65.0 \pm 3.82$ & $7.28 \pm 0.31$ & $6.87 \pm 0.35$ & $26.02 \pm 1.54$ & $5.07 \pm 0.35$ \\
\hline & 30 & $31.0 \pm 8.08$ & - & $13.0 \pm 6.83$ & - & - & - & - \\
\hline \multirow{5}{*}{ Rox } & 0 & $97.0 \pm 3.46$ & $1.96 \pm 0.13$ & $91.0 \pm 8.24$ & $9.66 \pm 0.67$ & $7.92 \pm 0.45$ & $88.47 \pm 7.36$ & $9.35 \pm 0.46$ \\
\hline & 5 & $96.0 \pm 3.26$ & $1.95 \pm 0.09$ & $78.0 \pm 8.32$ & $10.13 \pm 0.61$ & $7.97 \pm 0.65$ & $79.32 \pm 8.35$ & $8.37 \pm 0.82$ \\
\hline & 10 & $90.5 \pm 1.91$ & $2.33 \pm 0.09$ & $43.5 \pm 10.63$ & $10.18 \pm 0.58$ & $7.35 \pm 0.75$ & $69.32 \pm 9.07$ & $7.42 \pm 0.79$ \\
\hline & 20 & $69.0 \pm 8.08$ & $3.78 \pm 0.09$ & $0.0 \pm 0.0$ & - & - & - & - \\
\hline & 30 & $43.0 \pm 10.00$ & - & $0.0 \pm 0.0$ & - & - & - & - \\
\hline \multicolumn{2}{|c|}{$\mathrm{LSD}_{\text {int }}(\mathrm{P}<0.05)$} & 7.58 & 0.19 & 7.87 & 1.56 & 1.09 & 7.61 & 0.93 \\
\hline
\end{tabular}

*, data represent mean \pm standard deviation $(\mathrm{SD})$ of four replicates 
Table 2- Germination and seedling growth of sorghum cultivars under different drought stress*

Çizelge 2-Farklı kuraklık streslerinde sorgum çeşitlerinin çimlenme ve fide gelişsimi*

\begin{tabular}{|c|c|c|c|c|c|c|c|}
\hline $\begin{array}{l}\text { Sorghum } \\
\text { cultivars }\end{array}$ & $\begin{array}{l}P E G \\
\text { (bar) }\end{array}$ & $\begin{array}{c}\text { Germination } \\
(\%)\end{array}$ & $\begin{array}{l}M G T \\
\quad(d)\end{array}$ & $\begin{array}{l}\text { Root length } \\
\text { (cm) }\end{array}$ & $\begin{array}{l}\text { Shoot length } \\
(\mathrm{cm})\end{array}$ & $\begin{array}{c}\text { Seedling fresh } \\
\text { weight } \\
\left(\text { mg plant }^{-1}\right)\end{array}$ & $\begin{array}{c}\text { Seedling dry } \\
\text { weight } \\
\left(m g \text { plant }{ }^{-1}\right)\end{array}$ \\
\hline \multirow{5}{*}{ Aldarı } & 0 & $100.0 \pm 0.00$ & $1.96 \pm 0.02$ & $10.52 \pm 0.72$ & $11.17 \pm 0.38$ & $85.87 \pm 5.13$ & $10.40 \pm 0.33$ \\
\hline & -1.8 & $96.0 \pm 1.63$ & $1.70 \pm 0.13$ & $11.57 \pm 1.04$ & $6.62 \pm 0.27$ & $29.00 \pm 1.41$ & $9.42 \pm 0.20$ \\
\hline & -3.6 & $99.0 \pm 1.15$ & $1.99 \pm 0.07$ & $8.83 \pm 1.35$ & $4.50 \pm 0.21$ & $22.00 \pm 0.81$ & $7.42 \pm 0.28$ \\
\hline & -7.2 & $91.5 \pm 7.18$ & $2.49 \pm 0.21$ & - & - & - & - \\
\hline & -10.8 & $28.5 \pm 4.12$ & - & - & - & - & - \\
\hline \multirow{5}{*}{ Akdarı } & 0 & $98.0 \pm 2.82$ & $2.59 \pm 0.08$ & $8.57 \pm 1.17$ & $8.41 \pm 0.42$ & $84.77 \pm 8.73$ & $8.60 \pm 0.64$ \\
\hline & -1.8 & $94.5 \pm 4.12$ & $3.02 \pm 0.12$ & $7.10 \pm 1.00$ & $5.56 \pm 0.45$ & $16.75 \pm 1.50$ & $6.17 \pm 0.45$ \\
\hline & -3.6 & $89.5 \pm 2.51$ & $3.56 \pm 0.46$ & $6.45 \pm 0.87$ & $2.60 \pm 0.17$ & $11.75 \pm 1.25$ & $4.07 \pm 0.18$ \\
\hline & -7.2 & $33.5 \pm 7.54$ & - & - & - & - & - \\
\hline & -10.8 & $0.00 \pm 0.00$ & - & - & - & - & - \\
\hline \multirow{5}{*}{ Beydar1 } & 0 & $96.5 \pm 3.00$ & $2.18 \pm 0.06$ & $10.83 \pm 1.59$ & $7.22 \pm 0.31$ & $24.02 \pm 0.55$ & $7.97 \pm 0.25$ \\
\hline & -1.8 & $98.5 \pm 1.00$ & $2.03 \pm 0.07$ & $11.95 \pm 0.44$ & $6.75 \pm 0.20$ & $26.75 \pm 2.36$ & $9.02 \pm 0.45$ \\
\hline & -3.6 & $97.0 \pm 3.46$ & $2.19 \pm 0.20$ & $8.83 \pm 1.25$ & $5.46 \pm 0.64$ & $23.00 \pm 3.74$ & $7.45 \pm 0.55$ \\
\hline & -7.2 & $76.0 \pm 6.53$ & $2.84 \pm 0.31$ & - & - & - & - \\
\hline & -10.8 & $13.0 \pm 5.77$ & - & - & - & - & - \\
\hline \multirow{5}{*}{ Gözde 80} & 0 & $78.5 \pm 5.25$ & $2.94 \pm 0.11$ & $13.26 \pm 1.09$ & $8.57 \pm 0.49$ & $73.90 \pm 7.71$ & $7.72 \pm 0.43$ \\
\hline & -1.8 & $84.0 \pm 8.79$ & $2.57 \pm 0.16$ & $11.08 \pm 0.28$ & $9.28 \pm 0.90$ & $29.00 \pm 2.16$ & $7.00 \pm 0.00$ \\
\hline & -3.6 & $70.0 \pm 9.09$ & $2.94 \pm 0.06$ & $10.41 \pm 0.24$ & $7.38 \pm 0.45$ & $28.25 \pm 1.70$ & $6.25 \pm 0.50$ \\
\hline & -7.2 & $27.0 \pm 3.82$ & - & - & - & - & - \\
\hline & -10.8 & $0.00 \pm 0.00$ & - & - & - & - & - \\
\hline \multirow{5}{*}{ Greengo } & 0 & $99.0 \pm 1.15$ & $2.14 \pm 0.15$ & $12.61 \pm 1.56$ & $9.33 \pm 0.87$ & $58.75 \pm 18.13$ & $6.52 \pm 2.52$ \\
\hline & -1.8 & $96.5 \pm 1.00$ & $1.39 \pm 0.15$ & $9.77 \pm 1.36$ & $8.82 \pm 0.46$ & $25.50 \pm 3.78$ & $8.00 \pm 0.57$ \\
\hline & -3.6 & $92.0 \pm 4.89$ & $1.92 \pm 0.08$ & $9.51 \pm 1.48$ & $5.87 \pm 0.96$ & $28.00 \pm 4.76$ & $7.25 \pm 0.50$ \\
\hline & -7.2 & $74.5 \pm 7.72$ & $2.60 \pm 0.06$ & - & - & - & - \\
\hline & -10.8 & $14.5 \pm 8.38$ & - & - & - & - & - \\
\hline \multirow{5}{*}{ Leoti } & 0 & $100.0 \pm 0.0$ & $1.99 \pm 0.03$ & $11.18 \pm 1.55$ & $10.25 \pm 0.86$ & $77.52 \pm 4.13$ & $9.37 \pm 0.09$ \\
\hline & -1.8 & $99.5 \pm 1.00$ & $1.91 \pm 0.02$ & $13.33 \pm 1.74$ & $9.90 \pm 0.24$ & $37.00 \pm 3.16$ & $8.50 \pm 0.57$ \\
\hline & -3.6 & $99.0 \pm 2.00$ & $2.00 \pm 0.05$ & $11.16 \pm 0.58$ & $8.60 \pm 0.54$ & $33.75 \pm 3.94$ & $7.50 \pm 0.57$ \\
\hline & -7.2 & $92.0 \pm 3.65$ & $2.50 \pm 0.17$ & - & - & - & - \\
\hline & -10.8 & $3.0 \pm 3.82$ & - & - & - & - & - \\
\hline \multirow{5}{*}{ Rox } & 0 & $97.0 \pm 3.46$ & $1.96 \pm 0.13$ & $9.66 \pm 0.67$ & $7.92 \pm 0.45$ & $88.47 \pm 7.36$ & $9.35 \pm 0.46$ \\
\hline & -1.8 & $97.5 \pm 2.51$ & $2.02 \pm 0.05$ & $9.01 \pm 0.51$ & $7.42 \pm 0.24$ & $30.00 \pm 2.70$ & $8.00 \pm 0.00$ \\
\hline & -3.6 & $96.0 \pm 1.63$ & $2.25 \pm 0.19$ & $9.60 \pm 1.36$ & $6.12 \pm 0.35$ & $30.25 \pm 2.50$ & $8.25 \pm 0.50$ \\
\hline & -7.2 & $36.0 \pm 7.11$ & - & - & - & - & - \\
\hline & -10.8 & $4.5 \pm 1.91$ & - & - & - & - & - \\
\hline $\mathrm{LSD}_{\text {int }}(\mathrm{P}<0.05)$ & & 6.38 & 0.20 & 1.23 & 0.57 & 6.14 & 0.74 \\
\hline
\end{tabular}

*, data represent mean \pm standard deviation $(\mathrm{SD})$ of four replicates 
In the seedling survival test, the sorghum seedlings started wilting 11 days after the drought incubation. Significant differences among the cultivars were determined $(\mathrm{P}<0.05)$. Aldar1 and Rox were the last cultivars to wilt while Akdarı and Gözde 80 died earlier (Table 3). Genotypic variation among the sorghum cultivars was determined. Seedlings began wilting after 13 days following drought incubation. The wilting sequence, from late to early, among cultivars was recorded as Alda rl $>$ Rox $>$ Beydarl $>$ Leoti $>$ Greengo $>$ Gözde $80>$ Akdarı, indicating that Akdarı was the first cultivar to wilt.

Table 3- Mean seedling wilting day of sorghum cultivars subjected to drought stress in the pod experiment

Çizelge 3- Saksl denemelerinde kurakllk stresi uygulanan sorgum çeşitlerinin ortalama fide kuruma süresi

\begin{tabular}{lc}
\hline Sorghum cultivars & Mean seedling wilting day $(d)$ \\
\hline Aldar1 & $15.36^{\mathrm{a}^{*}}$ \\
Akdar1 & $13.68^{\mathrm{c}}$ \\
Beydar1 & $14.26^{\mathrm{bc}}$ \\
Gözde 80 & $13.92^{\mathrm{c}}$ \\
Greengo & $14.22^{\mathrm{bc}}$ \\
Leoti & $14.25^{\mathrm{bc}}$ \\
Rox & $15.14^{\mathrm{ab}}$
\end{tabular}

*, different letters in each column indicate significance at $\mathrm{P}<0.05$

\section{Conclusions}

Differences in seed vigor were observed among the sorghum cultivars grown under identical conditions. By contrast, seed vigor was not related to the germination tests under salt and drought stress conditions, thereby suggesting that the cultivars with vigorous seeds did not perform better under the investigated stresses. This result suggests that there is no relationship between seed vigor and germination under abiotic stress conditions. Thus, it was concluded that seed vigor test results are not a reliable indicator of seed performance under salt and drought stress conditions.

\section{References}

Ambika R R, Muthiah A R, Manickam A, Shanmugasundaram P \& John J A (2011). Indices of drought tolerance in sorghum (Sorghum bicolor L. Moench) genotypes at early stages of plant growth. Research Journal of Agriculture and Biological Sciences 7: 42-46

Araus J L, Slafer G A, Reynolds M P \& Royo C (2002). Plant breeding and water relations in $\mathrm{C}_{3}$ cereals: What should we breed for? Annals of Botany 89: 925-940

Cisse N D \& Ejeta G (2003). Genetic variation and relationships among seedling vigor traits in sorghum. Crop Science 43: 824-828

Doggett H (1988). Sorghum. $2^{\text {nd }}$ ed. John Wiley and Sons, Inc, New York

El Naim A M, Mohammed K E, Ibrahim E A \& Suleiman N N (2012). Impact of salinity on seed germination and early seedling growth of three sorghum (Sorghum biolor L. Moench) cultivars. Science and Technology 2: $16-20$

Faheed F A, Hassanein A M \& Azzoz M M (2005). Gradual increase in $\mathrm{NaCl}$ concentration overcomes inhibition of seed germination due to salinity stress in Sorghum bicolor (L.). Acta Agronomica Hungarica 53: 229-239

Francois L E, Donovan T \& Maas E V (1984). Salinity effects on seed yield, growth and germination of grain sorghum. Agronomy Journal 76: 741-744

Hameed A, Gohler M \& Iqbal N (2010). Evaluation of seedling survivability and growth response as selection criteria for breeding drought tolerance in wheat. Cereal Research Communications 38: 193-202

Hampton J G \& TeKrony D M (1995). Handbook of vigour test methods. $3^{\text {rd }}$ ed. International Seed Testing Association, Zurich, Switzerland

Igartua E, Gracia M P \& Lasa J M (1994). Characterization and genetic control of germination, emergence responses of grain sorghum to salinity. Euphytica 76: 185-193

ISTA (2003). Handbook on seedling evaluation. 3 ed. International Seed Testing Association, Zurich, Switzerland

Kandil A A, Sharief A E, Abido W A E \& Ibrahim M M (2012). Effect of salinity on seed germination and seedling characters of some forage Sorghum cultivars. International Journal of Agricultural Sciences 4: 306311 
Kaur Gill P, Sharma A D, Sing P \& Bhullar S S (2002). Osmotic stress-induced changes in germination, growth and soluble sugar content of Sorghum bicolor (L.) Moench seeds. Bulgarian Journal of Plant Physiology 28: 12-25

Khan M A \& Gulzar S (2003). Germination responses of Sporobilus ioclados: A saline desert grass. Journal of Arid Environments 53: 387-394

Maiti R K, Ibarra M R \& Sandoval N (1994). Genotypic variability in glossy sorghum lines for resistance to drought, salinity and temperature stress at the seedling stage. Journal of Plant Physiology 143: 241-244

McDonald M B (1993). The history of seed vigour testing. Journal of Seed Technology 17: 93-104

Michel B E \& Kaufman M R (1973). The osmotic potential of polyethylene glycol-6000. Plant Physiology 51: 914-916

Milosevic M, Vujakovic M \& Karagic D (2010). Vigour tests as indicators of seed viability. Genetika 42: 103118

Munns R (2002). Comparative physiology of salt and water stress. Plant Cell and Environment 25: 239-250

Mutavaa R N, Prasada P V V, Tuinstrab M R, Kofoidc K D \& Yua L J (2011). Characterization of sorghum genotypes for traits related to drought tolerance. Field Crop Research 123: 10-18
Saint-Clair P M (1976). Germination of Sorghum bicolor (L.) Moench under PEG-induced stress. Canadian Journal of Plant Science 56: 21-24

Santipracha W, Santipracha Q \& Wongvarodom V (1997). Hybrid corn seed quality and accelerated ageing. Seed Science \& Technology 25: 203-208

Smith R L, Hoveland C S \& Hanna W W (1989). Water stress and temperature in relation to seed germination of pearl millet and sorghum. Agronomy Journal 81: 303-305

Soares M M, Conceição P M, Dias D C F S \& Alvarenga E M (2010). Testes para avaliação do vigor de sementes de sorgo com ênfase à condutividade elétrica. Ciência e Agrotecnologia 34: 391-397

Tabatabaei S A \& Anagholi A (2012). Effects of salinity on some characteristics of forage sorghum genotypes at germination stage. International Journal of Agriculture and Crop Sciences 4(14): 979-983

Tari I, Laskay G, Takacs Z \& Poor P (2013). Response of sorghum to abiotic stresses: A review. Journal of Agronomy and Crop Sciences 199: 264-274

TeKrony D M \& Egli D B (1991). Relationship of seed vigor to crop yield: A review. Crop Sciences 31: 816822 